\title{
A mikroszkópos colitis rejtekútjai
}

| Mihály Emese dr. ${ }^{1}$, Berczi Lajos dr. ${ }^{2}$, Herszényi László dr. ${ }^{3}$, Tulassay Zsolt dr. ${ }^{1}$

${ }^{1}$ Semmelweis Egyetem, II. sz. Belgyógyászati Klinika, Budapest; ${ }^{2}$ Toldy Ferenc Kórház, Patológiai Osztály, Cegléd

${ }^{3}$ Magyar Honvédség Egészségügyi Központ, Gasztroenterológiai Osztály, Budapest

Correspondes: emesemihaly@hotmail.com

A mikroszkópos colitis ( $\mathrm{MC}$ ) az utóbbi évtizedben a figyelem előterébe került, amelyet a kórkép gyakoribb felismerése és a kóreredettel kapcsolatos számos új adat magyaráz. Az MC incidenciája egyes népességben elérte a gyulladásos bélbetegségek szintjét. Kialakulásával kapcsolatban számos tényező szerepe vetődött fel: az immunológiai eredet, genetikai hajlam, hormonális háttér és jelentőssé vált a mikrobiom és gyógyszerek szerepe is. Az MC-ről azonban számos kérdés még megválaszolatlan. Így a hagyományos gyulladásos bélbetegségekhez való viszonya, és magyarázatot igényel az egyes kórformák egymásba való átfordulásának oka és jelentősége is. A gyógyításban a helyi szteroid elsődleges jelentőségű, előfordulnak azonban nem befolyásolható esetek is, amelyek immunmodulátor vagy biológiai kezelést is szükségessé tehetnek.

KULCSSZAVAK: mikroszkópos colitis, kollagén colitis, limfocitás colitis, kóreredet, természetes lefolyás

\section{Concealments of microscopic colitis}

Microscopic colitis (MC) has come to the highlight in the last decade, which is explained by the more frequent recognition of the disease and a number of new available data related to the pathogenesis. The incidence of $M C$ has reached the level of inflammatory bowel disease in some populations. A number of factors have been implicated in its development: immunological origin, genetic predisposition, hormonal background, the role of microbiome and drugs has also become significant. However, many questions about MC remain unanswered. Thus, its relationship to traditional inflammatory bowel diseases and the reason and significance of the subtypes transformation to each other also needs to be explained. Topical steroids are of primary importance in therapy, but there are also uncontrollable cases that may require immunomodulatory or biological treatment.

KEYWORDS: microscopic colitis, collagen colitis, lymphocytic colitis, pathogenesis, natural course

A mikroszkópos colitis (MC) elnevezés arra utal, hogy ebben a kórformában endoszkópos vizsgálattal ép vastagbél-nyálkahártya látható és csak a biopsziás minta szövettani vizsgálatával tárhatók fel kórjelző jellegzetességek. A kórkép első leírása 1976-ban történt. Lindstrom (1) középkorú nő kórtörténetét ismertette. A vizsgálat idült, vízszerű hasmenés és hasi fájdalom miatt történt, amely szabályos kolonoszkópos kép ellenére szövettannal szubepithelialisan kollagénköteget igazolt, amely egyébként kollagén sprue-ban is kialakul. A hasonló szövettani jelek miatt Lindstrom az eltérést kollagén colitisnek (CC) nevezte. Read 1980-ban azonos kórtörténetű betegében a szabályos kolonoszkópia során vett nyálkahártya-biopsziában enyhe, nem jellegzetes gyulladást észlelt, amelyet mikroszkópos colitisnek (MC) nevezett. E megfigyelésben jelenik meg elsőként ez az elnevezés (2). Read és mások hasonló közléseit és adatát újra vizsgálva Kingham és Levison arra a következtetésre jutott, hogy ezek az eltérések CC korai szakaszainak felelnek meg $(3,4)$. Lazenby 1989ben idült hasmenésben szenvedő betegének szabályos endoszkópiája során vett szöveti minta elemzésével az epitheliumban jelentős limfocitabeszűrődést észlelt, a lamina propria gyulladásával. Az eltérést limfocitás colitisnek (LC) nevezte (5). Az elnevezések hierarchiája az évek során megváltozott. Összefoglaló névként a mikroszkópos colitis vált elfogadottá, amelynek az LC és a CC két altípusát, formáját képviseli. A két forma szövettani eltérések alapján különíthető el.

Az idült, nem véres hasmenések 8-16\%-ának hátterében, ha a kolonoszkópia szabályos makroszkópos képet mutat, MC valószínű. Elsősorban 60 évnél idősebbekben mutatható ki, nőkben gyakrabban. A betegek 25\%-a 45 évesnél 
fiatalabb, sőt CC gyermekkorban is elöfordul (6). A CC nőkben 9-szer gyakoribb, mint férfiakban. A nemek közötti különbség LC-ben kisebb. Az MC világszerte egyre gyakoribb. A gyüjtött incidencia CC-ben 4,1, LC-ben 4,9 eset per 100 ezer személy/év (7).

$\mathrm{Az} M C$ incidenciája egyes népességben elérte az IBD szintjét, sőt a Crohn-betegségnél gyakoribbá is vált (8). A kórkép gyakoribb felismerésének hátterében valószínűleg a kolonoszkópia könnyebb elérhetősége és a gasztroenterológusoknak és a patológusoknak a fokozott figyelme és bővülő ismeretei állhatnak. Az MC prevalenciájában etnikai különbségek is megfigyelhetők (9). A fehér népességben és zsidókban gyakoribb, mint a nem fehér, a kelet-ázsiai és a hispániai lakosságban. Az eddigi adatok szerint az MC nem fokozza a colonkarcinóma kockázatát $(10,11)$.

\section{Kóreredet}

Az MC kialakulásának biológiai módja nem tisztázott, valószínüleg több tényező függvénye. A jellemző szövettani eltérések és a klinikai tünetek különböző hatásokra alakulhatnak ki $(12,13)$. Az MC elsősorban az immunrendszer közvetítésével fejlödik ki a szerzett immunrendszer és a

\section{1. ábra: A mikroszkópos colitis kóreredetének főbb tényezői}

A gyulladásos folyamat (kaszkád) elindítói gyógyszerek és baktériumok. Luminális antigének nagy számban jutnak a bélnyálkahártyába, csökkentik az epithelium védekezését (barrier), növelik az áteresztőképességét és átjárhatóvá teszik a baktériumok számára. Az MC és a coeliakia HLA genetikai átfedése a lamina propriába kialakuló kóros antigénbemutatásra utal. Ez fokozza a Th1- és Th17-immunválaszt Tc1 és Tc17 mediált citotoxicitást.

Az MC-t kóros szerotonin- (5-HT) visszavétel is jellemzi, amely növeli az 5-HT szintjét és közremüködnek a bél motilitás és szekréció fokozásában.

A profibrinogén citokinek (TGF-béta, IL-6 és IL-22) fokozott mennyisége a nyálkahártyában elsősorban kollagén colitisre jellemző és segítik a kollagén subepithelialis lerakódását.

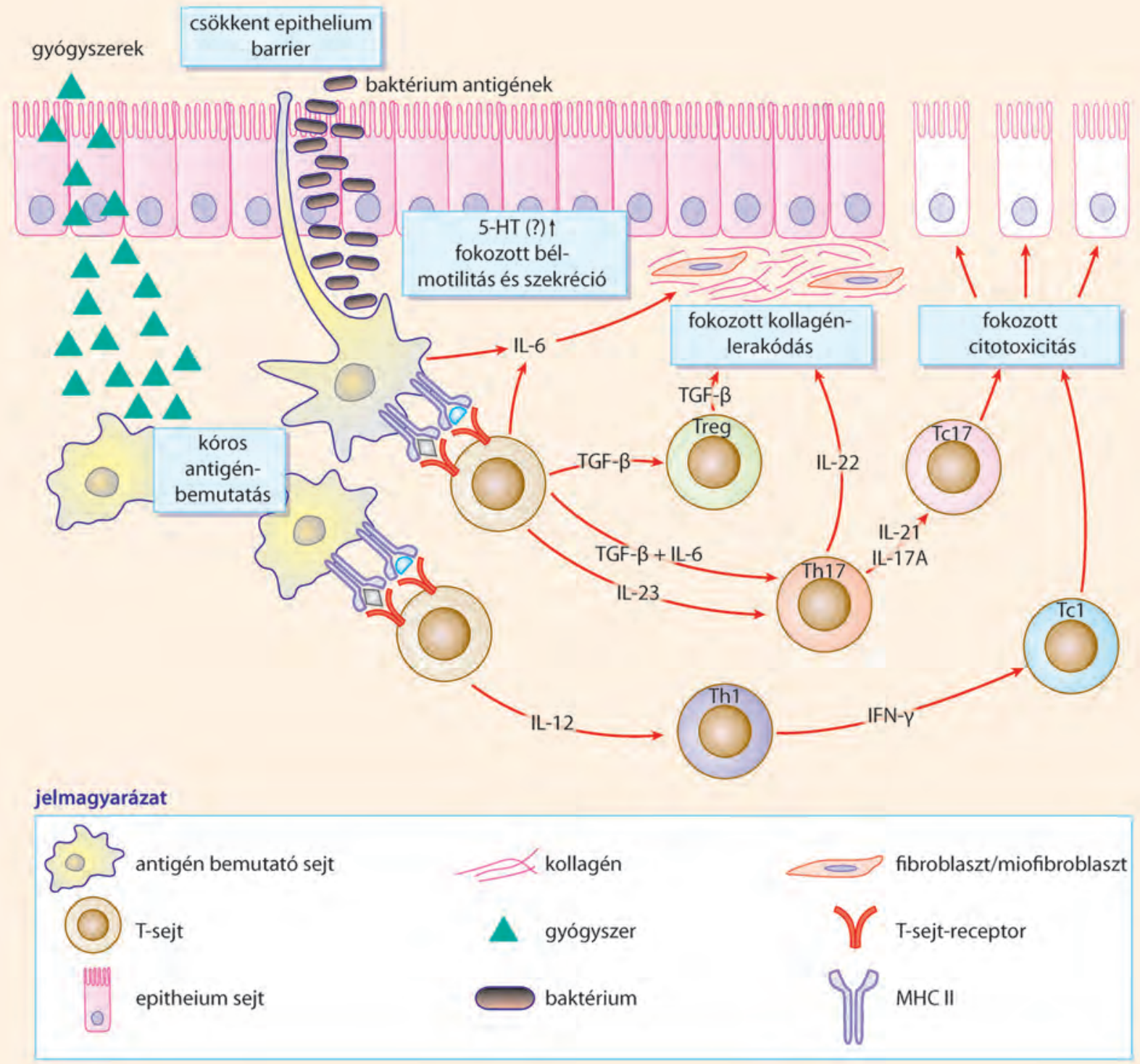




\section{1. táblázat: Citokinek kifejeződése mikroszkópos colitisben $(16,17,18$ alapján)}

\begin{tabular}{|c|c|c|}
\hline Citokin & $\mathrm{LC} / \mathrm{CC}$ & Hatás \\
\hline TNF $\alpha$ & $\uparrow$ & A veleszületett immunválaszt növeli \\
\hline $\mathrm{IFN \gamma}$ & $\uparrow$ & $\begin{array}{l}\text { Növeli a bélben a limfocitabeszűrődést, csökkenti a bélbarriert, aktiválja } \\
\text { a makrofágokat }\end{array}$ \\
\hline $\mathrm{IL}-1 \beta$ & $\uparrow$ Csak CC-ben & Neutrofilek begyűjtése; NOS-indukció \\
\hline IL-6 & $\uparrow$ & Neutrofilek begyűjtése; NOS-indukció \\
\hline IL-12 & $\uparrow$ & A lamia propria mononuclearis sejtjei révén fokozza az IFN $\gamma$-termelődést \\
\hline IL-15 & $\uparrow$ & Növeli az IEL-aktivitást és fokozza proliferációját \\
\hline IL-17A & $\uparrow$ & $\begin{array}{l}\text { TNF } \alpha \text { IL-1; IL-6-felszabadulást segíti; neutrofilek begyűjtése, NOS-indukció, } \\
\text { tight-junction erősítése; antimikrobás fehérjék indukálása }\end{array}$ \\
\hline IL-21 & $\uparrow$ & Pleitrop és proinflammatorikus hatás \\
\hline IL-22 & $\uparrow$ & $\begin{array}{l}\text { TNF } \alpha \text {-t és IL-8-t indokolja; myofibroblastokat kollagéntermelésre serkenti; } \\
\text { a betegség aktivitásával összefügg }\end{array}$ \\
\hline IL-23 & $\uparrow$ & TNF $\alpha$-t, IL-1-t és IL- $\gamma$ és IL-6-t indukálja neutrofilek begyűjtése. NOS-indukció \\
\hline IL-37 & $\downarrow$ & A gyulladás fenntartása \\
\hline
\end{tabular}

citotoxikus válaszok döntő részvételével. Az ellenőrizetlen immunreakciók különböző luminalis és nyálkahártyahatásokra, genetikailag hajlamos egyénekben jelennek meg. Autoimmun történések szerepe is valószínű, amelyet például a coeliakiával való összefüggése is alátámaszt (13.) Az immunológiai folyamatok elindítója a béllumenből a nyálkahártyába jutó serkentő hatások, baktériumok és exogén toxinok lehetnek (1. ábra).

Az MC immunmediált eltérés a szerzett immunrendszer és a citotoxikus válaszok elsődleges részvételével. Az immunitást befolyásoló tényezők, mikrobiológiai hatások, exogén toxinok a bél lumenéből áthelyeződnek a nyálkahártya rétegeibe.

Valószínúleg ez az elsődleges biológiai változás, amely MC-ben az immunológiai-gyulladásos rendszert (kaszkád) elindítja: a claudin-1 és occludin tight-junction fehérjék csökkent kifejeződését és a bél áteresztőképességének fokozódását $(14,15)$.

MC nyálkahártyájában változatos citokinösszetétel alakul ki a T-helper (Th) 1, és a citotoxikus T-sejtek (Tc) 1 vagy a Th17 és Tc17 megjelenésével, amely a tumornekrózis-faktor- (TNF) alfa, interferon-gamma és számos interleukin $(17,21,22,23)$ fokozott kifejeződéséhez vezet $(16,17,18)$ (1. ábra) (1. táblázat). Ez a molekuláris eseménysor segíti a bélben, az intraepithelialis rétegben a limfocitabeszűrődés kialakulását, gátolja az aktiválódott T-sejtek, az eozinofilek eliminációját, a makrofágok aktivációjának, a neutrofilek felszaporodásának, a nyálkahártya károsodott áteresztőképességének és a kollagénlerakódásnak a megszűnését. Számos, az MC-ben fokozottan termelődő proinflammatorikus citokin segíti a fibrosis kialakulását is (19). A VEGF növekedett kifejeződése az epitheliumban és a felszaporodó gyulladásos sejtek és fibroblastok a kollagénlerakódás döntő tényezői (20).

Bár LC-ben és CC-ben számos szabályozó és végrehajtó folyamat közös, immunológiai tulajdonságaik összessége eltérő, olyan jellegzetes limfocitasajátosságokkal, amelyek révén a luminális serkentő folyamatokra, a nyálkahártyabarrier kóros működésére és a HLA összefüggésekre különböző válaszok alakulnak ki. Ezt segíti a bél növekedett áteresztőképessége és a tight-junction fehérjék csökkent kifejeződése (21). A változó citokinprofil, a tumornekrózisfaktor-alfa és a különböző interleukinok fokozott kifejeződéséhez vezet (22) (1. táblázat).

Mivel az MC menopauzában lévő nőkben gyakoribb, kóreredetében hormonok szerepe is felvetődött. Burke és munkatásai 275 MC-ben szenvedő, posztmenopauzás nő adatát elemezték (23). A betegeket a hormonpótló kezelés szerint osztályozva azt tapasztalták, hogy a múltban történt hormonpótlás az MC kockázatát 1,95-szeresére $(0,5 \% \mathrm{Cl}: 1,37-2,78)$, a jelenleg is zajló kezelés pedig 2,64-szeresére (95\% Cl: 1,78-3,90) növelte. Vizsgálták azt is, hogy a kórelőzményben szereplő per os hormonális fogamzásgátlás befolyásolja-e az MC kockázatát. A kockázat növekedésének mértéke 1,57-nek $(95 \% \mathrm{Cl}$ : 1,16-2,13) bizonyult (23).

A bélbaktériumok összetételének változása az utóbbi években a gyulladásos bélbetegségek kóreredetének vizsgálatakor fontos tényezővé vált. Különböző eltérések derültek ki a mikrobiom összetételében és változatosságában egyaránt, egyértelmű kóroki szerepük azonban még nem igazolódott. Aktív MC-ben többek között az Akkermansia-fajok csökkenését is kimutatták (24). Morgan az aktív szakaszban és a remisszióban lévő MC-ben szenvedők bélmikrobiom összetételében jelentős különbséget észlelt, amely a mikrobiom sokszínűségében (diverzitás) és a dysbiosis mértékében mutatkozott meg (25). A dysbiosis-index aktív MC-ben szignifikánsan növekedettebb, mint a remisszióban lévőké, az idült funkcionális hasmenésben szenvedőké és az egészségeseké. Az Alistipes putredinis relatív menynyisége a mikrobiomban azonban MC-ben csökkent 


\section{2. táblázat: Mikroszkópos colitist okozó gyógyszerek}

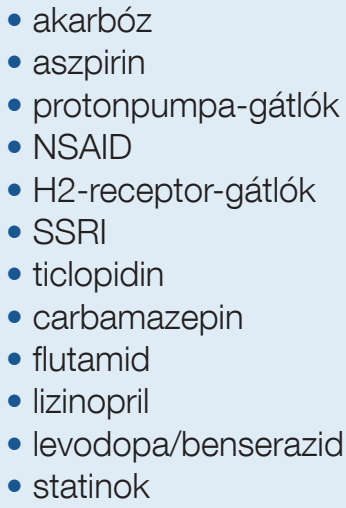

Rövidítések: NSAID: nem szteroid gyulladásgátlók SSRI: szelektív szerotonin-visszavételt gátlók

mindkét vizsgálati csoporthoz viszonyítva. Az Alistipes-fajok gyulladásgátló tulajdonságú butiráttermelő baktériumok, amelyek mennyisége újonnan kialakult gyermekkori IBD-ben csökkent (26). A glikogenezis és inozin-5'-foszfát bioszintézis III. metabolizmus aktív MC-ben csökkent, míg a purin dezoxiribonukleotidlebontás fokozódott az egészségesekével összehasonlítva. A glükóz bioszintézisében és az oxidatív stresszben szereplő metabolikus utak relatív fokozódása MC-ben, a fokozott purinlebontás következménye. Morgan vizsgálata arra utal, hogy a dysbiosis a gyulladásos bélbetegséghez hasonlóan, MC-ben is a bélmikrobiom fontos jellemzője (25). Az azonban nem bizonyított, hogy ez az eltérés elsődleges kóreredeti tényező lenne, mivel következményes jelenségként is kialakulhat.

A genetikai hátteret vizsgálva a humán leukocitaantigénnel (HLA) való összefüggés adatai ellentmondásosak, de a coeliákiával jelentős átfedés észlelhető (27). Az interleukin (IL)-6, -174 gén polimorfizmusa és az MC-nek az összefüggésre is utalnak adatok. Ez a polimorfizmus növekedett IL-6-termelődéshez vezet, amely hatékonyan segíti a gyulladást és a fibrózist.

A matrix metalloproteinázok (MMPs) különböző kifejeződése is szerepet játszhat a CC kóreredetében (13). Az MMPs a gyulladásos folyamatokat követő újrarendeződés (remodelling) fontos résztvevői: genetikai polimorfizmusuk CCre hajlamosíthat. A GG-allélt hordozó MMP-9-gén növeli a CC kockázatát (13). Az MMP9 kóros aktivitása, a kollagénleépülés zavarához vezethet.

Az MC-t kiváltó kockázati tényezők közül a gyógyszermellékhatás a legjelentősebb. Az MC-t okozó gyakoribb gyógyszereket a 2. táblázat foglalja össze. A protonpumpa-gátlók (PPI) okozta MC kórfolyamatának részletei nem ismertek. A protonpumpák azonban nemcsak a gyomor, hanem a vastagbél nyálkahártyájában is jelen vannak, így az egész szervezet káliumforgalmát érintik. A colonnyálkahártya protonpumpájának gátlása befolyásolja az elektrolitok helyi egyensúlyát, kiegyenlítik a folyadék savasságát, amely a vastagbél-nyálkahártya immunfolyamatait is befolyásolja. A PPI okozta hypomagnesiaemia a

\section{3. táblázat: A vízszerü hasmenés lehetséges okai, ha a kolonoszkópia szabályos képet mutat}

- Mikroszkópos colitis

- Coeliakia

- Fertőzéses colitis (pl. cryptosporidiosis)

- Vékonybél baktériumfertőzöttsége (SIBO)

- Giardiasis

- Epesav felszívódásának zavara

- Epehólyag eltávolítása utáni epecsorgás

- Neuroendokrin daganatok

- Hashajtóabúzus

- lleumelhelyezkedésű Crohn-betegség

- Gastrocolicus sipoly

- Szénhidrát-felszívódási zavar (pl. laktóz, szorbitol)

- Irritabilis bélszindróma

magnéziumfelszívódás zavarának következménye lehet. A PPI károsítja a magnéziumfelszívódás fontos elemeit a tight junction fehérjéket és a TRPM6 és -7 csatornákat (transient receptor potential melastin-6 és -7) (13.), a pHeltérések pedig a csatornák és a tight junctionok működését. A PPI növeli a fibrosist elősegítő tényezőket is, így a TGF-bétát, a fibroblast növekedési faktor-2-t és a III. és IV. típusú kollagént (28) CC-ben a COX2 mértéke a vastagbél-nyálkahártyában növekszik (29). A COX2 tartós gátlása segíti a myofibroblasttal összefüggő intestinalis fibrosist (30). Egyéb kockázati tényezők a dohányzás és az alkoholfogyasztás. A dohányzás elsősorban a CC kockázatát fokozza (OR: 5,5; 95\% Cl: 3,4-8,9) az LC-t kevésbé (OR: 2,96; 95\% Cl: 2,0-4,3) (31).

A hasmenés MC-ben több tényező következménye.

Ezek a következők:

- ozmózis;

- csökkent felszívódás: LC-ben a vastagbél epithelium nátriumcsatornái gátoltak (32), a széklet, a béllumen nitricoxid és az epithelium nitric-oxid-szintetáz szintje növekedett (34);

- a klorid aktív szekréciója CC-ben (14);

- az epithelium-barrier kóros müködése (35);

- az aquaporinok kóros szabályozása;

- kóros motilitás (36);

- az epesavak károsodott felszívódása (37).

\section{Tünetek, természetes lefolyás}

A mikroszkópos colitis tünete az idült, vízszerü hasmenés, amely görcsös hasi fájdalommal társulhat. Átmeneti panaszmentes szakasz után a hasmenés akár évek múlva is visszatérhet. Általános tünetek is észlelhetők: fogyás, fáradtság, vérszegénységgel összefüggő panaszok.

A mikroszkópos colitis természetes lefolyására a tünetmentes és a hasmenéssel járó szakaszok váltakozása a jellemző. A tünetek kezelés nélkül akár évekre is megszűnhetnek. A tüneteket a budesonid hatékonyan befolyásolja, elhagyásakor a panaszok a betegek 80\%-ában 3 hónapon belül visszatérnek. A visszatérő tünetek ellenére a beteg- 
2. ábra: Mikroszkópos colitis szövettani képe

A: Limfocitás colitis szövettani képe: a felszíni hámsejtek között a limfociták felszaporodtak (hematoxilin-eozin 400x)

B: Kollagén colitis: kiszélesedett subepithelialis kollagénréteggel (picro-sirius festés, 400x)

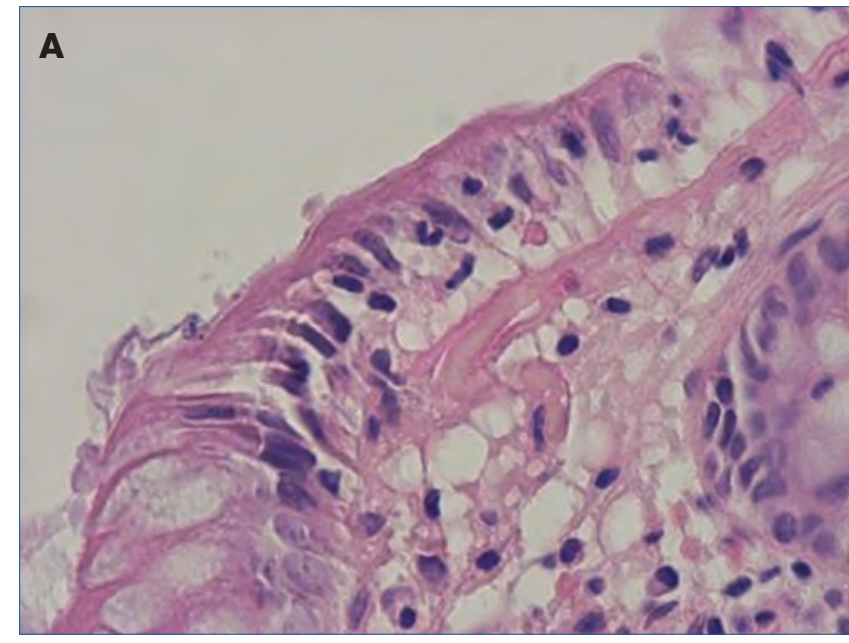

ség nem rosszabbodik, nem jár a halálozás fokozott kockázatával és a vastagbél rosszindulatú daganata sem alakul ki gyakrabban mikroszkópos colitis talaján (11).

\section{Kórisme}

Kórismének három meghatározó tényezője a következő:

- jellegzetes tünetek,

- normális kolonoszkópia,

- kórjelző szövettani kép.

A tünetek és a szabályos makroszkópos kép számos kórkép jellemzője lehet, amelyet az elkülönítésben tekintetbe kell vennünk (3. táblázat).

Sem laboratóriumi eltérés, sem biomarkerek (pl. calprotectin) nem kórjelző értékűek. Különböző kockázati tényezők és tünetek figyelembevételével pontrendszert is kidolgoztak az MC kórisméjének azonosítására, amely azonban jelenleg biztos támpontot nem jelent (38).

A kolonoszkópos kép többnyire normális, bár nem fajlagos eltérések (hyperaemia, ödéma, az érrajzolat csökkenése, foltos erythema) előfordulhatnak (39).

Az LC szövettani jellegzetessége az intraepithelialis lymphocytosis (IEL). A feltétel az, hogy hematoxilin-eozin festéssel 100 felszíni epithelialis sejtből legalább 20 IELs legyen. A normális érték nem haladja meg az 5-öt. A felszíni epithelium enyhén károsodott lehet és a subepitheliumban kevés kollagén rakódik le. Ha az IELs száma határérték, immunohisztológia ajánlott, amellyel az intraepithelialis T-sejtek kimutathatók. Az immunohisztológia érzékenyebb módszer, több, IELs-t mutat ki, mint a hematoxillin-eozin, ezért a kórisme, különösen határesetekben a rutinfestéssel nehézséget okoz (40) (2. A, 2. Bábra).

A CC kórisméjének feltétele a felszíni epithelium alatt a kollagén köteg megvastagodása, amelynek a kórisméhez $10 \mu \mathrm{m}$-ot meg kell haladnia. A felszíni epithelium is károsodott lehet és az IELs sejtek száma is növekedhet, de nem éri el az LC-re jellemző értéket. Az esetek több-

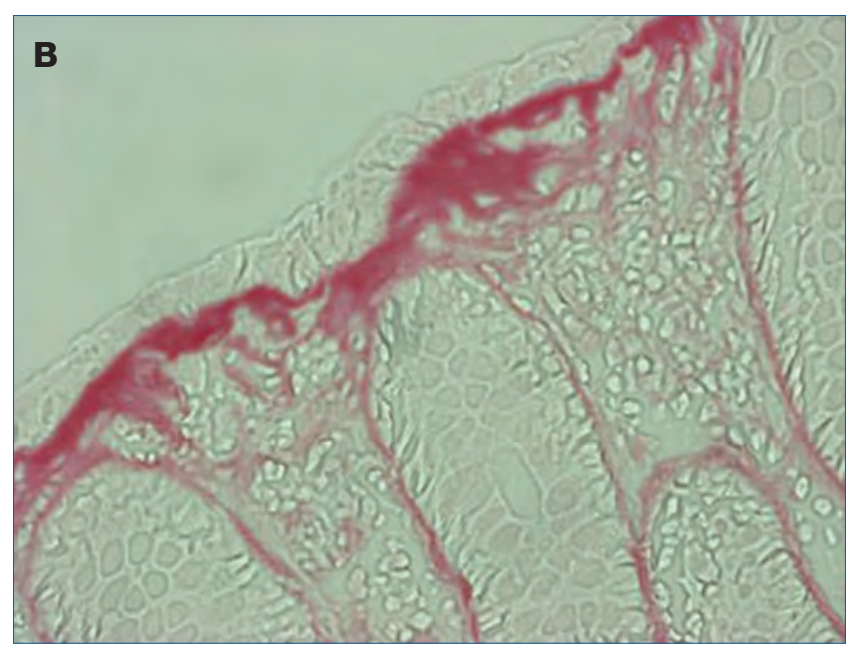

ségében a hematoxillin-eozin festés kórjelző, határesetekben azonban kötőszöveti festés is szükséges (3. $A, B$, C, Dábra).

Mindkét szövettani formában az epithelium sérült, nyák rakódik le, vaszkularizáció észlelhető. A lamina propriában gyulladásos beszűrődés alakul ki, plazmasejtekkel, limfocitákkal, eozinofilokkal, mastocytákkal, olykor Paneth-sejt metaplasiával és cryptitissel (3. $A, B, C, D$ ábra).

Nem teljes (inkomplett) mikroszkópos colitisben (MCi) az LC és a CC kórisméjének feltételei nem teljesülnek teljes mértékben. Növekszik ugyan az IELs sejtek száma és a kollagénköteg szélessége is, de nem éri el a kórjelző határértéket $(41,42,43)$ (4. ábra).

A kórisméhez alapvető a biopsziák helyének és számának megválasztása. Az MC foltokban is kialakulhat, a sejtszaporulat és a kollagén megvastagodása a colon különböző helyein változó, ezért a nem érintett szakaszból vett biopszia tévedés forrása is lehet. A különböző colonszakaszokban nincs a kórismét segítő kitüntetett terület. A kórisméhez ezért minden colonszakaszból legalább 8 biopszia szükséges $(39,44)$.

\section{Kezelés}

\section{Budesonid}

Az MC kezelésének első vonala a kortikoszteroidok második generációjához tartozó, helyileg ható budesonid, amely a gyulladás helyén, a sejten belüli glükokortikoid jelfogókhoz érzékenyen kötődik. Jelentős (kb. 90\%) a firstpass metabolizmusa a vékonybél-nyálkahártyában és a májban, ezért a szerveket érintő általános hatása csekély, amely a leépítő kezelési módot nem teszi szükségessé.

Kafil metaanalízisében négy véletlen besorolású, placebóval ellenőrzött vizsgálat adatait dolgozta fel és bemutatta, hogy 6-8 hét kezelés után a budesoniddal kezelt betegek 81\%-a javult, amely jelentősen különbözött a placebocsoporttól (36\%) (45). A szövettani gyógyulás is halmozottabb volt a budesonidcsoportban (78\% vs. 32\%). A tünetek, a vízszerü hasmenés 2 héten belül javultak. A 9 mg/nap 
3. ábra: Mikroszkópos colitis szövettani képe

A: Limfocitás colitis, felszaporodott limfociták (hematoxilin-eozin 100x)

B: Limfocitás colitis (hematoxilin-eozin 400x)

C: Kollagén colitis: subepithelialisan felszaporodott kollagén, gyulladásos beszürődés a lamina propriában és a felszíni epitheliumon degeneratív elváltozások. Goldner staining (10x).

D: Kollagén colitis: a felszíni hám alatt vaskos kollagénréteg élénkvörös színben. A felszíni hámsejtek rendezetlenek, az IEL-szám növekedett, a felszín közelében a strómában plazmasejtes-limfocitás beszürődés (picro-sirius festés, 10x)
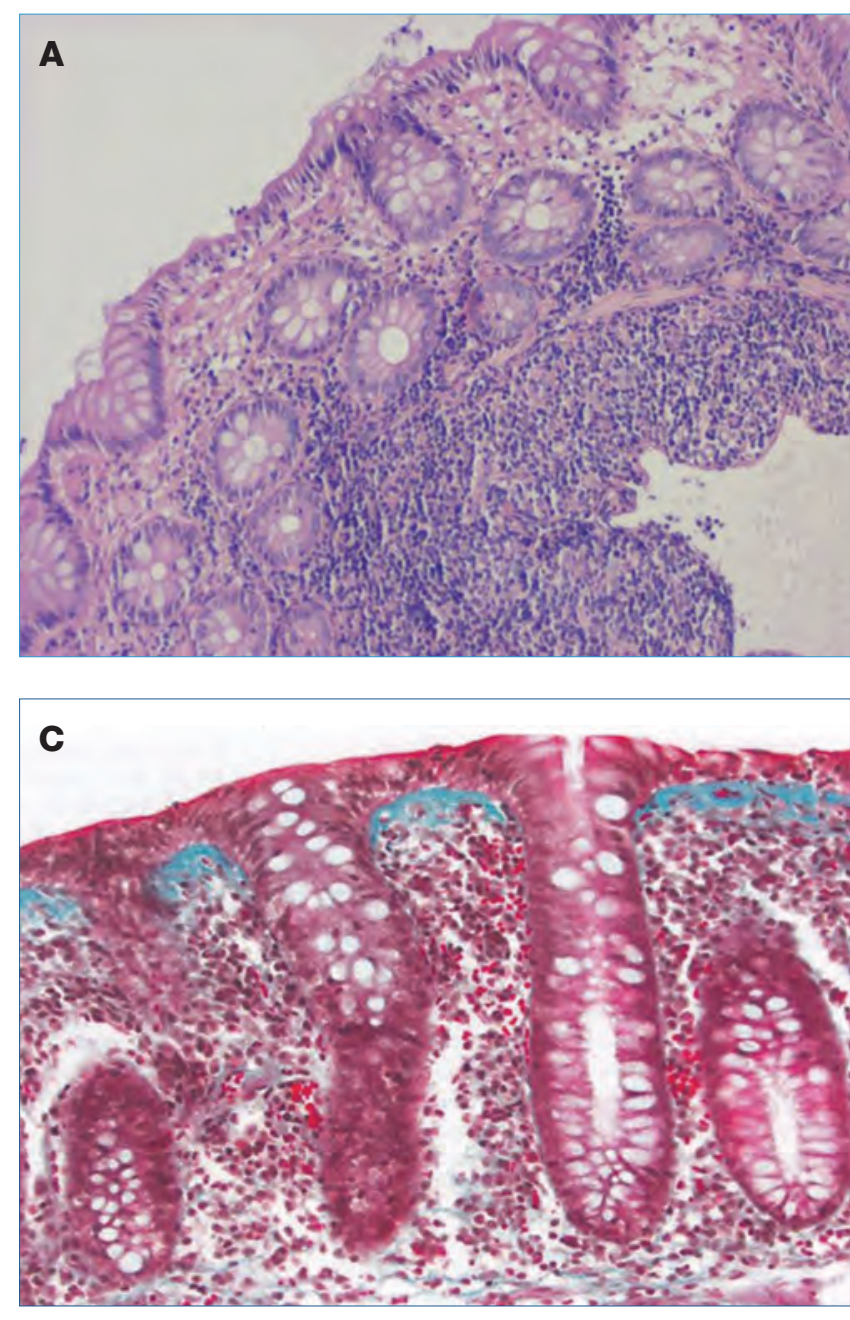

budesonid indukciós kezelés mind LC-ben $(46,47)$, mind CC-ben $(48,49)$ hatékony. A kezelés elhagyásakor azonban elsősorban CC-ben a tünetek 60-80\%-ban visszatérnek (50). Két véletlen besorolású vizsgálat szerint 6 hónapon át adott napi $6 \mathrm{mg}$ budesoniddal a javulás a CC-betegek 75\%-ában fenntartható volt, míg a placebocsoportban ez az arány 25\%-nak bizonyult (45). Az LC fenntartó kezeléséről nem történt ellenőrzött vizsgálat, de a tapasztalatok a szükségességet erősítik.

\section{Egyéb gyulladás- és szekréciógátlók}

A prednisolon a budesonidnál kevésbé hatékony $(51,52)$, és a tünetek is gyakrabban térnek vissza. Munck placebóval ellenőrzött vizsgálatában a prednisolon hatástalannak bizonyult (53). A mesalasin ( $M$ ) hatását budesoniddal (B) és placebóval $(P)$ összehasonlítva a mesalazin az MC mindkét formájában elmaradt a budesonid eredményességétől (CC: B: 80\%, M: 44\%, P: 38\%; LC: B: 79\%, M: 63\%, P: 42\%) (54).
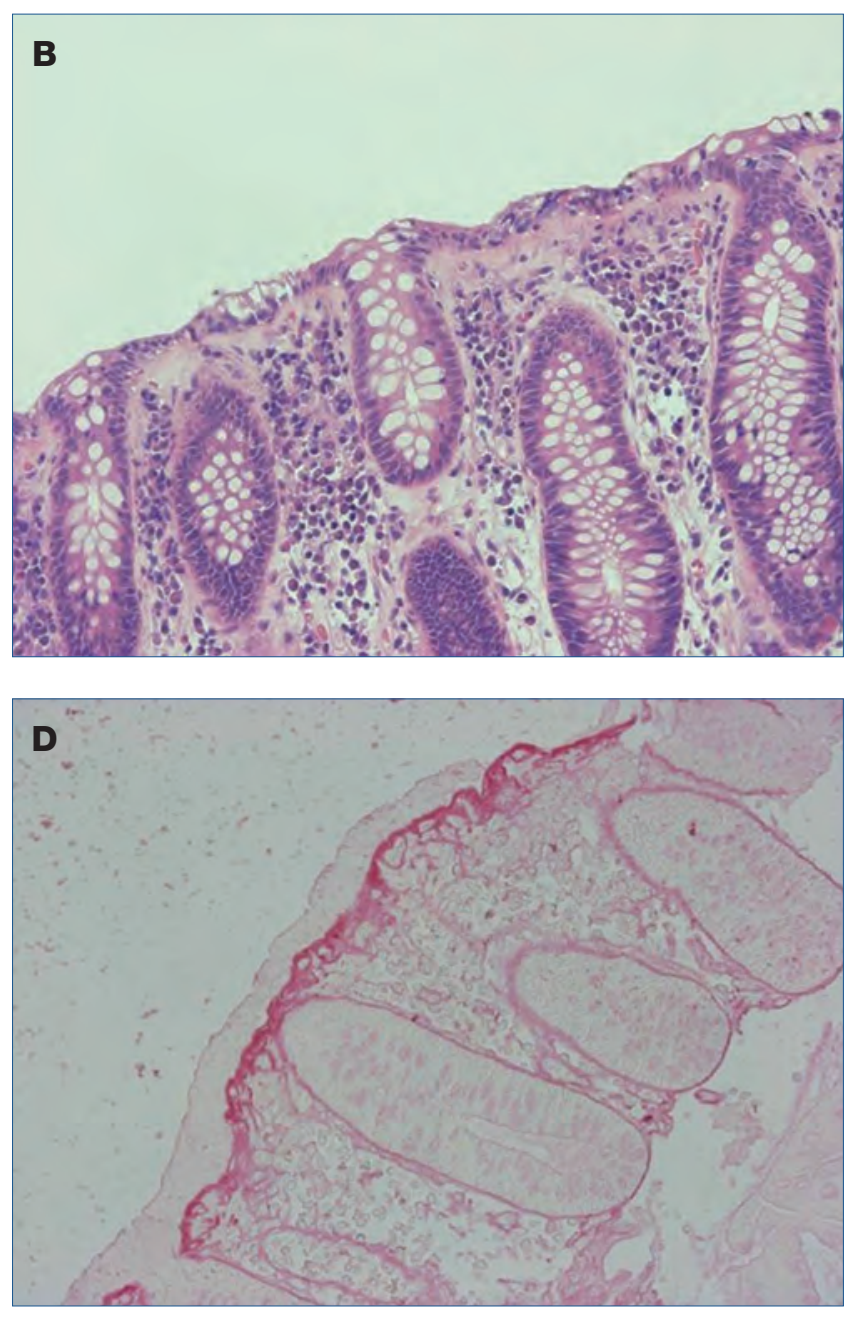

A bizmut-szubszaliciláttal nem történtek széles körű vizsgálatok, a szórványos adatok szerint azonban a placebónál hatékonyabb. A loperamid enyhe MC-ben a tünetekre kedvező hatású, rendszerezett vizsgálatokat azonban e szerrel sem végeztek. Ha az MC-ben az epesavak hasmenést okozó hatása is kimutatható, cholestyramin jól befolyásolja a tüneteket (55).

\section{Immunmodulátorok}

Cotter 49, MC-ben szenvedő beteget kezelt átlagosan 4 hónapig thiopurinnal (57). A CC-betegek 43\%-ában, az LCben szenvedők 23\%-ában tapasztalt javulást. Retrospektív elemzésben 49 beteg (43 azathioprin, 6 mercaptopurin), 43\%-a, illetve 22\%-a tapasztalt javulást, míg 17 súlyos mellékhatások miatt elhagyta a kezelést (57). A metothrexattal egy prospektív vizsgálat történt 9 olyan betegben, akik budesonidra nem válaszoltak, vagy a kezelést nem viselték. Közülük egy sem tapasztalt javulást (58). 


\section{4. ábra: A mikroszkópos colitis formái}

Az ún. nem teljes (inkomplett) formákban a jellegzetes tünetek és a gyulladás ellenére a kollagénréteg vastagsága és az intraepithelialis limfociták (IEL) száma nem éri el a kórisméhez elfogadott mértéket

$\begin{array}{cccc}\text { Kollagén colitis } & \begin{array}{c}\text { Inkomplett kollagén } \\ \text { colitis }\end{array} & \begin{array}{c}\text { Lymphocytás colitis } \\ \text { Kollagénréteg } \\ \text { vastagsága }\end{array} & \begin{array}{c}\text { Kollagénréteg } \\ \text { vastagsága }\end{array} \\ >10 \mu \mathrm{m} & 5-10 \mu \mathrm{m} & \text { IEL-szám } & \text { IEL-Szám } \\ \text { colitis }\end{array}$

\section{Biológiai kezelés}

Biológiai szerekkel nem történtek nagy betegszámú öszszehasonlító vizsgálatok. E szerek ugyanis jelenleg csak második vonalban jönnek szóba, elsősorban akkor, ha a budesonid hatástalan. TNF-alfa-antagonisták közül az infliximabról és az adalimumabról jelentek meg esetismertetések és néhány beteg adatát bemutató leírások. $\mathrm{A}$ legnagyobb betegszámot Daferera közölte (18 MC-ből 16 CC, 2 LC) (59). Tizenkét hét kezelés 9 betegben ért el javulást és 6 bizonyult sikeresnek. Az integrin-gátlók közül a vedolizumab kezelésről közöltek 11 olyan betegről (5 LC, 6 CC) adatot (60), akikben egyéb szer nem volt eredményes. Három infúzióval 5 beteg (2 LC és 3 CC) állapota javult, és a 13 hónapos fenntartó kezeléssel 3 maradt remisszióban. Számos sikeres esetközlés is ismert $(61,62,63)$.

\section{Székletátültetés}

Az első székletátültetést (fecal microbiota transplantation, FMT) CC-ben Ginaltay közölte (64). A kezelést a budesonid hatástalansága indokolta. Három FMT után a beteg pana- szai megszűntek. Holster 10 CC-beteg FMT kezeléséről számolt be (65). Az FMT javallata azonban még bizonytalan, az eredmények pedig egyelőre nem meggyőzőek.

\section{Ajánlás}

Az aktív MC kezelésére leginkább a budesonid hatékony, amely egyébként az egyetlen ebben a javallatban is regisztrált készítmény. Idült betegségállapotokban csökkentett alapú fenntartó kezelés célszerü. Egyéb kezelési módok, csak második vonalban, a budesonid hatástalanságakor jönnek szóba (5. ábra).

\section{A rejtekutak irányai}

A bővülő ismeretek ellenére az MC-ről még számos ismeret felfedezésre vár (64). Megválaszolatlan kérdés a kórkép besorolása, a gyulladásos bélbetegséghez való viszonya, az, hogy valóban önálló egységnek (entitás) tekinthető-e, vagy a szervezet különböző hatásokra adott válaszának (reakció)

\section{5. ábra: Az aktív mikroszkópos colitis kezelésének vázlata}

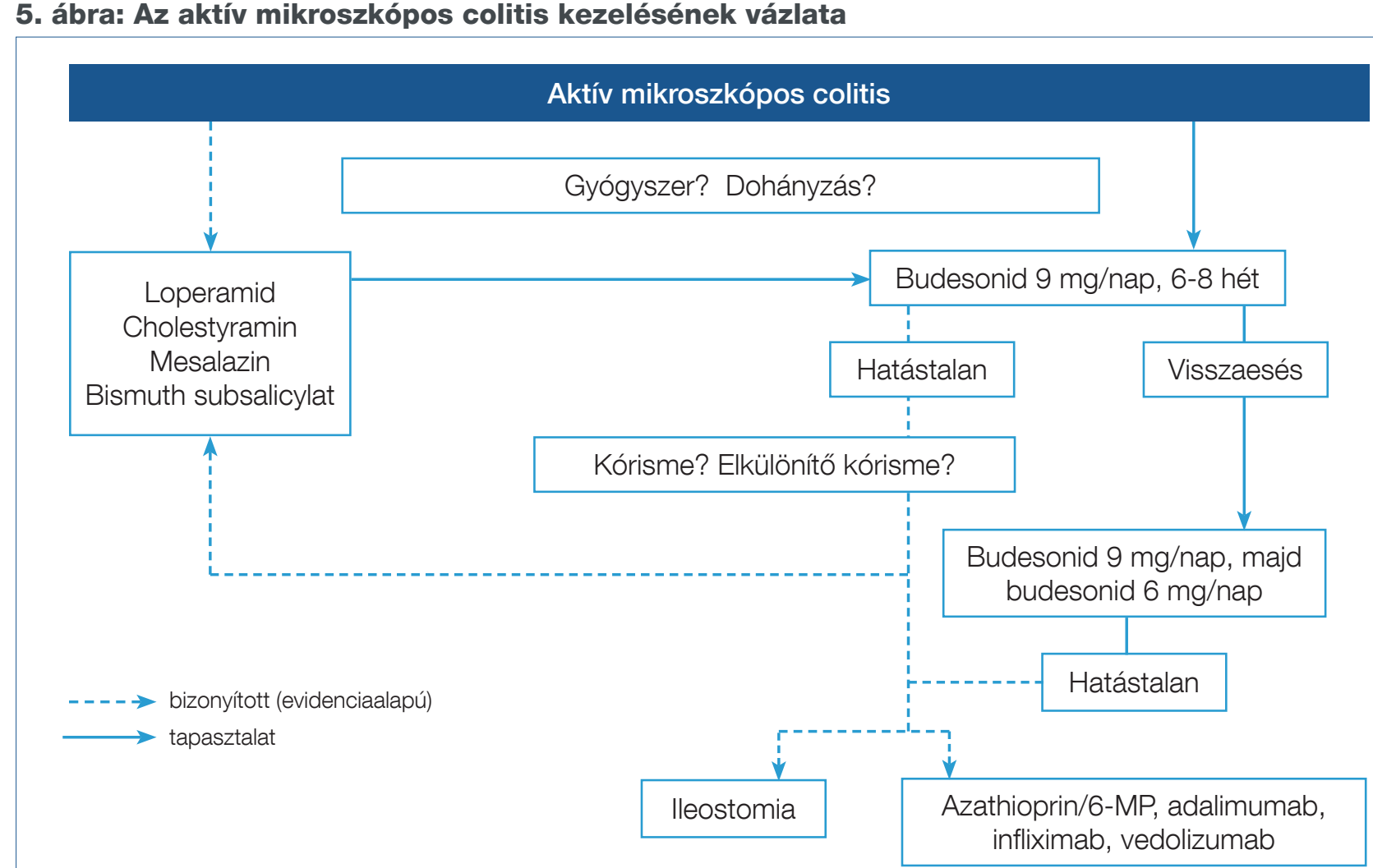


és olyan köztes állapotnak, amely kibontakozásának iránya számos tényező együtthatásának eredménye. A bizonytalanság egyik alapja az a tény, hogy az MC formái egymásba és a klasszikus gyulladásos bélbetegségbe átalakulhatnak, és az IBD-vel genetikai azonosságok mutathatók ki.

A MC két formája szövettani jelek alapján elkülöníthető egymástól. Az ún. inkomplett eltérés (MCi) meghatározását is egyértelműnek látszó feltételek segítik. Ez alapján nem vonható kétségbe az az álláspont, hogy az LC és CC ugyanannak a kórképnek két különböző megjelenése lenne. Az MC-ben szenvedők hosszabb távú ellenőrzése azonban figyelemreméltó és magyarázatot is igénylő összefüggést tárt fel. Rasmussen és munkatársai 1055, MC-ben szenvedőből (468 CC; 361 LC; 226 MCi) 283 beteg ismételt kolonoszkópos és hisztológiai vizsgálatát is elvégezték (67) 149 (32\%) CC, 72 (20\%) LC és 62 beteg (27\%) MCi). Az ellenőrzések a kórisme után 12 hónapon belül, 13-24 hónap között és 24 hónappal utána történtek. A szövettani kórisme a CC-betegek 83\%-ában, LC-ben 63\%-ban, MCiben 54\%-ban nem változott. Az egyes formákra jellemző eltérések azonban 107 betegben (26\%) módosultak: a korábban megállapított kórisme helyett a másik MC forma jegyei jelentek meg (CC: 22; LC:39; MCi: 44 beteg). A változások nagyobb számban több mint két évvel a kórisme után derültek ki (CC: 15; LC: 19; MCi: 44 beteg). A CC kórisme 13 betegben LC-re, 9-ben MCi-re változott. Az LC átfordulásának iránya a következő: CC: 31, MCi: 8. Az MCi változása: 30 CC-be 14 LC-be alakult át.

Vigren 65 MC-ben szenvedő beteg (CC: 47; LC: 18) legalább 3 hónap különbséggel végzett kolonoszkópos és szövettani eredményét tekintette át (68). Az ellenőrzés 9 betegben a kórforma átalakulását igazolta: háromban CC fordult LC-be, hatban pedig az LC CC-be. A 47 CC-esetből 17-ben a szövettani kép normálissá vált, 27-ben az MC nem változott. Az LC-betegek közül négynek változatlan maradt a szövettani lelete, míg nyolcban szabályos szerkezet derült ki.

Ung 23, LC-ben szenvedő endoszkópiáját 4 év múlva megismételve két betegében CC megjelenését észlelte (69). Olesen 25, LC-ben szenvedő betegét két év múlva ellenőrizve azt tapasztalta, hogy kilencben a szövettani kép normálissá vált, 11-ben LC továbbra is kimutatható volt, ötben pedig CC alakult ki (70).

Az egyes formák átalakulásának háttere nem ismert. Vigren áttekintette a betegek gyógyszeres kezelésének módját is feltételezve, hogy a változás, az átalakulás a kezelés következménye lenne. A gyógyszerek és a szövettani kép átfordulása között azonban nem talált összefüggést (68).

Az MC-ben végzett ellenőrző kolonoszkópia eredményének értékelésekor figyelembe kell vennünk a mintavétellel összefüggő hiba lehetőségét is. A kollagénréteg foltokban is megvastagodhat, normális méretű nyálkahártya-szerkezettel váltakozva. Kevés biopsziás minta ezért tévedés forrása lehet. Az MC kórisméjében a mintaszámból adódó hiba lehetőségének elkerülésére a vastagbél minden szakaszából (szegmentum) két biopszia ajánlott. A mintavétel módja is befolyásolja a kórisme biztonságát. A subepithelialis kollagénréteg vastagságának megállapítására a nyálkahártyát csak érintőleg elvégzett biopszia nem alkalmas.
Az LC téves kórisméjéhez vezethet a felszaporodott limfoid folliculusok területéből vett szövettani minta, amelyben sok intraepithelialis limfocita látható. Ez azonban csak helyi jelenség, a vastagbél-nyálkahártya egészére ez az eltérés nem vonatkoztatható.

A CC átváltozása az LC-hez képest kisebb arányú, amelynek magyarázatára több lehetőség vethető fel. A CC a kórkép aktívabb és állandóbbnak tartható formája, mivel a kialakult kollagénköteg kevésbé visszafordítható (reverzibilis), mint az intraepithelialisan felszaporodó limfociták számának változása. Ezek ugyanis mozgékonyabbak és az epitheliumba vándorolva számuk hullámzó lehet.

$A z$ inkomplett $M C$ változása a leggyakoribb, amely azzal magyarázható, hogy az MCi az MC kezdeti formája lehet és a szöveti eltérések a kollagén és az intraepithelialis limfociták felszaporodása, bár nem kórjelző mértékben, de megfigyelhető. A kórfolyamatot kiváltó hatásoktól függően a szöveti szerkezet mindkét forma irányába fordulhat.

A szövettani átalakulások az MC megítélésében újabb szempontokat is fölvethetnek:

- nem zárható ki az a lehetőség, hogy miképp a két klasszikus formától az inkomplett MC is megkülönböztethető, az egymásba átalakuló típusok is önálló egységet képviselnek (71).

- A kórkép a természetes lefolyása során is módosulhat, amely az MC jellegzetességének is felfogható. Ennek a lehetőségnek a bizonyítására az eddigi adatok nem elégségesek. Homogén adatok rendszerezése segíthet a kérdés eldöntésében.

- A szövettani mintavétel helye és feldolgozása is tévedés forrása lehet. Az eltérő helyekről származó és többféle festési eljárással kezelt biopszia különböző szöveti szerkezetet tárhat fel.

Kórszövettani elemzések arra utalnak, hogy a klasszikus gyulladásos bélbetegségek, a kórfolyamat kezdetén, vagy bizonyos szakaszaiban mikroszkópos colitis szövettani eltéréseivel járhatnak (72). Esetismertetések olvashatók arról, hogy a CC súlyos colitis ulcerosába $(73,74)$, illetve Crohn-betegségbe is átalakulhat (75).

A gyulladásos bélbetegségek és az MC összefüggéséről Khalili és munkatársai 27 éven át tartó svédországi prospektív vizsgálatról közöltek összegző adatokat (77). Huszonhétéves megfigyelésük alatt, 28 svédországi gasztroenterológiai központban 13957 MC kórisme született. Az MC-betegek adatait az egészséges átlagos népességével ( $n=66820)$ hasonlították össze. Az MC-betegekben a megfigyelési időszakban 323 UC és 108 CD alakult ki. Az egészséges népességben az IBD megjelenése lényegesen kevesebb volt (UC: 94; CD: 42). Az IBD az MC fennállásának átlagosan harmadik évében alakult ki. Khalili eredménye szerint az MC az IBD relatív kockázatát 17-szeresére növeli. Kisebb betegszám és rövidebb megfigyelési idő alapján más szerzők ezt az összefüggést nem igazolták $(77,78)$.

Az IBD és az MC kialakulásának pontos módja nem ismert ugyan, kóreredetükben azonban számos közös tényező mutatható ki (79).

- A HLA haplotípus DQ2 és DQ8, valamint az MC kockázatának összefüggése ismert (80). Westerling az IBD és az 
MC fenotípusa között az egyszeres nukleotid polimorfizmusban (single nucleotide polymorph, SNPs) jelentős átfedést igazolt (81). Green teljes genom elemzése öszszefüggést mutatott ki (genom-wide-association study, GWAS) a 8.1 haplotípussal, amely az MC kialakulásának hátterében az immunösszetevő jelentőségére utal (82). Genetikai kockázati score számítással az MC és a Crohnbetegség között tapasztalható csak azonos irány, a colitis ulcerosával azonban nem. Ez az adat a két IBD forma eredetének genetikai különbözőségét támogatja. Green adatai megerősítik az MC és a coeliakia fenotípusának összefüggését, amely további magyarázatot jelenthet a két kórkép gyakori együttes előfordulására (83).

- Az IBD és az MC kialakulásában a mikrobiom szerepe, a jelentős dysbiosis és a csökkent sokszínűség (diverzitás) egyre inkább a figyelem előterébe kerül.

- A limfocitás colitis szövettani képében el nem sajtosodó granuloma és a crypta szerkezetének károsodása is megfigyelhető, hasonlóan az elsősorban Crohn-betegségben észleltekhez (84).

- MC-ben a nyálkahártya immunválaszában a proinflammatorikus citokinek kifejeződése (pl. interferon-gamma, tumornekrózis-faktor-alfa, IL-17 stb.) fokozott (1. táblázat), amely gyulladásos bélbetegségekben is megfigyelhető. Ennek alapján az is felvethető, hogy az MC az IBD még nem kialakult kezdeti formája lenne, amelyben a nyálkahártya gyulladását az IL-10 gyulladásgátló hatása mérsékli, kiegyenlíti. Ha ez az ellensúlyozó hatás csökken, vagy megszűnik, a Th1- és a gyulladásos Th17-sejtek felszaporodnak és kialakulhat a klasszikusnak tartott gyulladásos bélbetegség.

A bélrendszeri gyulladásos folyamatok keletkezésének több részlete is ismert, amelyek különböző tényezők szerepét hangsúlyozzák és számos összefüggés valószínúségét vetik fel. Az új adatok azonban szerteágazóak és akadályozzák az egységes nézet, felfogásmód kialakulását. A mikroszkópos colitisre ez a helyzet különösen igaz, hiszen az eredmények gyakran vetnek fel kétségeket és újabb kutatási célokhoz vezetnek. Az MC-ről sok ismeret gyűlt össze, besorolását, feltételrendszerét nagyrészt elfogadható keretek határolják. A kétkedés, az ellentmondó álláspontok és tények azonban egyre több rejtekút irányába mutatnak, amelyek feltárása a jövő feladata lehet.

\section{Irodalom}

